\title{
Peptide YY: more than just an appetite regulator
}

\author{
Shanta J. Persaud • Gavin A. Bewick
}

Received: 25 February 2014 / Accepted: 8 May 2014 /Published online: 11 June 2014

(C) Springer-Verlag Berlin Heidelberg 2014

\begin{abstract}
Replenishment of beta cell mass is a key aim of novel therapeutic interventions for diabetes, and the implementation of new strategies will be aided by understanding the mechanisms employed to regulate beta cell mass under normal physiological conditions. We have recently identified a new role for the gut hormone peptide YY (PYY) and the neuropeptide Y (NPY) receptor systems in the control of beta cell survival. PYY is perhaps best known for its role in regulating appetite and body weight, but its production by islet cells, the presence of NPY receptors on islets and the demonstration that $\mathrm{Y} 1$ activation causes proliferation of beta cells and protects them from apoptosis, suggest a role for this peptide in modulating beta cell mass. This review introduces PYY and its potential role in glucose homeostasis, then focuses on evidence supporting the concept that PYY and NPY receptors are exciting new targets for the preservation of beta cells.
\end{abstract}

Keywords Apoptosis $\cdot$ Beta cells $\cdot$ Diabetes $\cdot$ Islets $\cdot$ NPY receptors $\cdot$ Peptide YY $\cdot$ Proliferation $\cdot$ Review

$\begin{array}{ll}\text { Abbreviations } \\ \text { ARC } & \text { Arcuate nucleus } \\ \text { BrdU } & \text { Bromodeoxyuridine } \\ \text { CCK } & \text { Cholecystokinin } \\ \text { E } & \text { Embryonic day } \\ \text { ERK } & \text { Extracellular signal-regulated kinases } \\ \text { GLP } & \text { Glucagon-like peptide } \\ \text { MAPK } & \text { Mitogen-activated protein kinase } \\ \text { NPY } & \text { Neuropeptide Y } \\ \text { NT } & \text { Neurotensin }\end{array}$

S. J. Persaud · G. A. Bewick $(\bowtie)$

Division of Diabetes \& Nutritional Sciences, King's College London,

Guy's Campus, London SE1 1UL, UK

e-mail: gavin.bewick@kcl.ac.uk
PDX-1 Pancreatic and duodenal homeobox 1

PK Protein kinase

PLC Phospholipase C

POMC Pro-opiomelanocortin

PP Pancreatic polypeptide

PYY Peptide YY

SP Substance P

STZ Streptozotocin

5-HT 5-Hydroxytryptamine

\section{Introduction}

Replenishment of beta cell mass is a key target of novel therapeutic interventions for insulin-dependent diabetes. Indeed, normoglycaemia is restored following islet transplantation, but only temporarily [1]. Apart from its transient nature, transplantation is associated with the risk of surgical morbidity, adverse effects of chronic immunosuppression and an insufficient supply of transplantable tissue. The need for alternative therapies is therefore urgent. The use of stem cells programmed to adopt a beta cell-like phenotype is one approach under investigation, but this is limited by the need to generate and then transplant the manipulated stem cells. Other strategies with high therapeutic potential are based on the exploitation of pre-existing cells within the islet itself. For example, current approaches include regeneration of beta cell mass from progenitor cells and reprogramming of acinar, ductal or alpha cells and expansion of the residual beta cells. Exploitation of these strategies and those that prevent beta cell death will rely on understanding the mechanisms employed to alter beta cell mass under normal physiological conditions, such as during pregnancy or in obesity, or preserving beta cell mass following injury. This will allow the identification of targets likely to repopulate and/or protect beta cell mass. In 
this vein we have recently identified that the gut hormone peptide YY (PYY) and the neuropeptide Y (NPY) receptor systems have a potential new role in the control of beta cell mass. This review introduces PYY and its potential role in glucose homeostasis, then focuses on evidence supporting the concept that PYY and NPY receptors are exciting new targets for the preservation of beta cell mass. We anticipate that such information will act as a springboard for further research in this area.

\section{Peptide YY}

PYY is a gut hormone that was first isolated from porcine intestine [2]. PYY and the related peptides NPY and pancreatic polypeptide (PP) are composed of 36 amino acids and their biological activity is dependent on the presence of an amide group at the C-terminus. In the adult, PYY can be detected at low levels in stomach enteroendocrine cells, and its concentration increases along the gastrointestinal tract such that its highest expression is in colonic and rectal L cells, where it colocalises with the pro-glucagon products glicentin, glucagonlike peptide (GLP)-1 and GLP-2 [3]. PYY 1-36 $_{\text {is a substrate }}$ for the proteolytic enzyme dipeptidyl peptidase IV (DPP-IV), which cleaves the N-terminal dipeptide to produce the major circulating form of PYY, $\mathrm{PYY}_{3-36}[4,5]$. PYY is also found centrally in neurons in the gigantocellular reticular nucleus of the hindbrain from which they project to the dorsal vagal complex and the hypoglossal nucleus [6]. Unlike in the circulation, the predominant form of PYY found in the brain is full-length $\mathrm{PYY}_{1-36}$ [7].

PYY is the first hormone identified in the colon during development, and its expression is apparent in mouse enteroendocrine cells as early as day 15.5 of gestation (E15.5) [8]. Expression of other gastrointestinal hormones such as GLP-1, cholecystokinin (CCK), neurotensin (NT), substance $\mathrm{P}$ (SP) and serotonin (also known as 5-hydroxytryptamine [5-HT]) occurs between days E16.5 and E18.5 in these early PYY cells [8]. These observations have led to the suggestion that a common PYY-expressing precursor cell gives rise to all colonic enteroendocrine cells. However, while the co-expression is maintained in some cell types throughout life, with approximately 50\% of GLP-1-, CCK- and NT-expressing cells also synthesising PYY, coexpression of SP and 5-HT in the same cells as any of PYY, GLP-1, CCK or NT is very rare in the adult [9]. It is therefore likely that $\mathrm{L}$ cells differentiate via two separate pathways, one of which culminates in cells that synthesise SP and 5-HT, while the other produces cells that synthesise GLP-1, PYY, NT and CCK [9]. Plasma PYY levels are lowest in the absence of food intake, and it is secreted from $\mathrm{L}$ cells within $30 \mathrm{~min}$ of a meal, in response to the presence of nutrients in the distal gastrointestinal tract [3]. Maximum PYY levels are observed in humans $1-2 \mathrm{~h}$ postprandially, and elevated levels are maintained for up to $6 \mathrm{~h}[10]$. As in the distal gut, PYY expression in the brain is nutritionally regulated, where states of energy deficit decrease PYY expression [7].

PYY is best known as an anorectic peptide, and $\mathrm{PYY}_{3-36}$ administration reduces food intake and weight gain [11-14], effects that are associated with increased c-Fos expression in the arcuate nucleus (ARC) [11]. There are conflicting data on the effect of $\mathrm{PYY}_{3-36}$ on arcuate food regulatory neurons. It was originally reported that $\mathrm{PYY}_{3-36}$ decreased the expression and secretion of the orexigenic neuropeptide NPY while stimulating activity of the anorexigenic pro-opiomelanocortin (POMC) neurons [11]. However, other investigators have demonstrated that $\mathrm{PYY}_{3-36}$ exerts inhibitory effects on POMC neurons through activation of postsynaptic $\mathrm{Y} 2$ receptors [15]. Moreover, mice in which POMC has been deleted respond appropriately to peripherally administered $\mathrm{PYY}_{3-36}$, with reductions in food intake, indicating that POMC is not essential for transducing the anorectic effects of $\mathrm{PYY}_{3-36}$. The circumventricular organs have been shown to play a role in the anorectic effects of PYY and its induction of c-Fos expression, since lesions of the area postrema and subfornical organ in rats reduced the effectiveness of peripheral PYY [16]. In addition to inhibiting food intake, PYY also delays gastric emptying, inhibits intestinal motility, increases fluid and electrolyte absorption from the ileum and decreases pancreatic secretions, and PYY locally produced in saliva has been implicated in modulating taste responsiveness by activation of Y2 receptors on taste buds [17-19].

\section{Peptide YY expression in the endocrine pancreas}

PYY is not only found in the gut and specific regions of the central nervous system (CNS), but is also present in the pancreas [20-22]. Since the gut and the pancreas share a common embryological origin (the pancreas arises from an out-pocket of the gut endoderm), it is not surprising that intestinal and pancreatic cell lineage commitment have overlapping transcription factor cascades. Furthermore, cell fate can be cross-committed during development. For example, exposure of intestinal progenitor cells to GLP-1 in vitro converts them into insulin-producing cells [23], suggesting the existence of a parallel developmental relationship between intestinal and pancreatic endocrine cells. In agreement with this, several studies have identified PYY expression in the pancreas during the earliest stage of pancreatic endocrine cell differentiation, when the pancreas buds from the foregut at E9.5 in mice $[24,25]$. A large proportion of these PYY-positive cells also express glucagon and insulin and, later in development, PYY is also found in cells that express somatostatin and PP $[25,26]$. However, as in the intestine, this co-expression pattern is altered in adults, and recombination- 
based cell lineage tracing studies have demonstrated that most islet alpha and beta cells in the adult are not direct descendants of PYY-positive cells, despite PYY promiscuity early in development [27]. However, around $40 \%$ of alpha cells are descended from PYY-positive cells [27] and, in the adult, PYY is also expressed by subpopulations of delta and PP cells $[21,25]$. These observations are consistent with PYY being present in a common islet progenitor cell but that its expression is silenced as beta cells mature [26]. They also implicate PYY in the regulation of islet endocrine cell development.

\section{NPY receptors in the brain and endocrine pancreas}

$\mathrm{PYY}_{1-36}$ and $\mathrm{PYY}_{3-36}$ exert their effects through the NPY family of G-protein-coupled receptors, which are also activated by NPY and PP. Four receptor subtypes (Y1, Y2, Y4 and Y5) have been identified in humans [28], all of which are widely distributed in the CNS and peripheral tissues. PYY ${ }_{1-36}$ binds with similar affinity to each of the NPY receptors, while $\mathrm{PYY}_{3-36}$ is a selective, high-affinity agonist of Y2 receptors [29]. Mice with targeted deletion of Y2 receptors are insensitive to the anorectic effects of PYY [11], while administration of a highly selective Y2 receptor antagonist (BIIE0246) directly into the ARC also attenuates PYY-induced reductions in food intake in rats [30]. These data implicate the ARC Y2 receptors as being key in transducing the anorectic effects of PYY [15]. However, there is evidence to suggest that $\mathrm{PYY}_{3-36}$ may act via stimulation of vagal afferents [31,32], in addition to its central actions. The role of $\mathrm{PYY}_{3-36}$ in energy homeostasis has put it in the spotlight as a candidate for novel obesity therapies, targeted either at regulating expression and release of PYY, or activating hypothalamic Y2 receptors.

The NPY receptors through which PYY acts are also expressed by a range of peripheral cells, including cardiomyocytes [33], adipocytes [34] and gut epithelial cells [35]. We have found that isolated human islets express mRNAs encoding Y1, Y4 and Y5 receptors (NPY1R, NPY4R, $N P Y 5 R$ mRNAs) [36], but the Y2 receptor (encoded by $N P Y 2 R$ ) that plays a key role centrally in mediating PYY effects to repress food intake is not present in human islets. In mouse islets and RIN 5AH rat insulinoma cells, expression of Npy1r, but not Npy5r, mRNA has been demonstrated [37, 38]. Our quantification of mouse islet NPY receptor mRNAs indicated that Npylr is the most abundant subtype, with lower concentrations of Npy4r mRNA (R. Drynda, G. A. Bewick, S. J. Persaud, unpublished results), and similar observations have recently been published [39]. We could not detect $N p y 5 r$ mRNA in mouse islets, in agreement with the earlier report [37], and Npy2r mRNA was not present in mouse islets, consistent with the human islet expression profile. Although antibodies for detection of NPY receptors by western blotting and immunohistochemistry are commercially available, to date there are no reports describing which cells of the endocrine pancreas express which of the receptor subtypes that have been detected in rodent or human islets at the mRNA level.

\section{Peptide YY effects on glucose homeostasis}

The synthesis of PYY in islet cells [26, 40] and our identification of NPY receptor expression by islets [36] suggests a potential paracrine role for this peptide in regulating islet function. In mice, intravenous administration of full-length PYY inhibits insulin secretion stimulated either by glucose or by the cholinergic agonist carbachol [21]. Consistent with this, PYY knockout mice are hyperinsulinaemic, which has been attributed to the absence of PYY, resulting in a loss of inhibitory tone on insulin release [41]. These inhibitory effects of PYY on beta cells are thought to occur through activation of Y1 receptors, since NPY and PP, both of which are agonists at Y1 receptors, inhibit insulin release from islets [42] and RIN insulinoma cells [38]. The capacity of $\mathrm{PYY}_{1-36}$ to directly inhibit insulin secretion has been confirmed by experiments using rat and mouse islets, which demonstrated that this peptide inhibits glucose-induced insulin release in vitro [39, 43]. In contrast to the inhibitory effects of full-length $P Y Y$ on insulin secretion, the truncated peptide $\mathrm{PYY}_{3-36}$, which selectively activates $\mathrm{Y} 2$ receptors, has no effect on glucosestimulated insulin secretion [39]. These observations are consistent with the absence of $\mathrm{Y} 2$ receptor expression by islets and imply that the inhibition of insulin release by $\mathrm{PYY}_{1-36}$ occurs via direct activation of islet $\mathrm{Y} 1$ and/or $\mathrm{Y} 4$ receptors. There may be species-specific effects of PYY on insulin secretion. Thus, although there is a consensus that the fulllength peptide inhibits insulin release in rodents, intravenous infusion of exogenous PYY into human volunteers did not affect glucose-induced insulin secretion [44]. The effects of $\mathrm{PYY}_{1-36}$ and $\mathrm{PYY}_{3-36}$ on insulin secretion from isolated human islets in vitro have not been reported, and this is clearly an area that requires further investigation.

PYY may also regulate glucose homeostasis through peripheral effects distinct from its interaction with islets. Peripheral administration of $\mathrm{PYY}_{3-36}$ or a Y2 receptor-selective agonist into mice improved glucose tolerance by increasing plasma insulin levels, an effect that was proposed to occur through increased GLP-1 secretion [39]. In addition, PYY $3-36$ may also regulate glucose homeostasis by improving insulin sensitivity, since intravenous $\mathrm{PYY}_{3-36}$ administration to insulin-resistant mice during hyperinsulinaemic-euglycaemic clamps increased their glucose disposal rate [45].

Taken together, these data support a direct inhibitory effect of locally produced $\mathrm{PYY}_{1-36}$ on insulin release, at least in rodents, and this may provide a paracrine physiological brake to the various stimulatory inputs that beta cells receive, thus 
ensuring sensitive regulation of insulin release. In contrast, circulating $\mathrm{PYY}_{3-36}$ is thought to improve glucose tolerance through indirect stimulation of insulin secretion via the release of GLP-1 from L cells and via improved insulin sensitivity.

\section{Peptide YY endocrine precursor cells and islet cell neogenesis}

The potential significance of PYY in fetal pancreas formation, as outlined above, suggests it could also be of importance in pancreatic tissue renewal in the adult mouse, and some supportive evidence is provided by the IFN $\gamma$ transgenic mouse [46]. In this mouse model, IFN $\gamma$ expression is driven in adult and precursor beta cells by the insulin promoter, and it exhibits spontaneous ductal hyperplasia and islet neogenesis throughout adulthood. IFN $\gamma$ transgenic mouse islets have increased numbers of PYY cells that co-express somatostatin, glucagon or PP, but, interestingly, there is no increase in cells that express both PPY and insulin. The specific accumulation of PYY-expressing cell types during pancreatic regeneration in the adult IFN $\gamma$ mouse may implicate PYY in driving islet endocrine cell expansion in this process. In addition, IFN $\gamma$ mice also exhibit greater numbers of PYY islet cells co-expressing pancreatic and duodenal homeobox 1 (PDX-1), a critical transcription factor controlling pancreatic development and a master switch controlling beta cell fate and identity. In agreement with this, PYY is also found in a subset of PDX-1-positive cells during the early development of embryonic stem cell cultures before they mature into adult islet cells [47]. Taken together, these observations are consistent with $\mathrm{PYY} \mathrm{PDX}^{+} 1^{+}$cells representing a pool of islet progenitor cells from which regeneration can occur. However, targeted deletion of PYY only prevents the development of PP islet cells, whereas the other endocrine cell types are unaffected, suggesting that PYY is only critical for the terminal differentiation of PP cells within islets [27]. PYY-expressing cells may therefore be important intermediaries in the transition from early pancreatic progenitor to fully mature adult islet endocrine cells, but it is likely that their role is permissive rather than essential, given that adult beta cells do not appear to be direct descendants of these cells [27]. In addition, it remains to be determined if PYY drives any of these regenerative processes in the pancreas, but clearly there is enough evidence to warrant further investigation of whether PYY is an important target for islet and beta cell regeneration.

\section{NPY receptor coupling and cell proliferation}

All NPY receptors couple primarily through $\mathrm{G}_{\mathrm{i} \alpha}$ to inactivate adenylate cyclase and decrease cAMP synthesis, with a

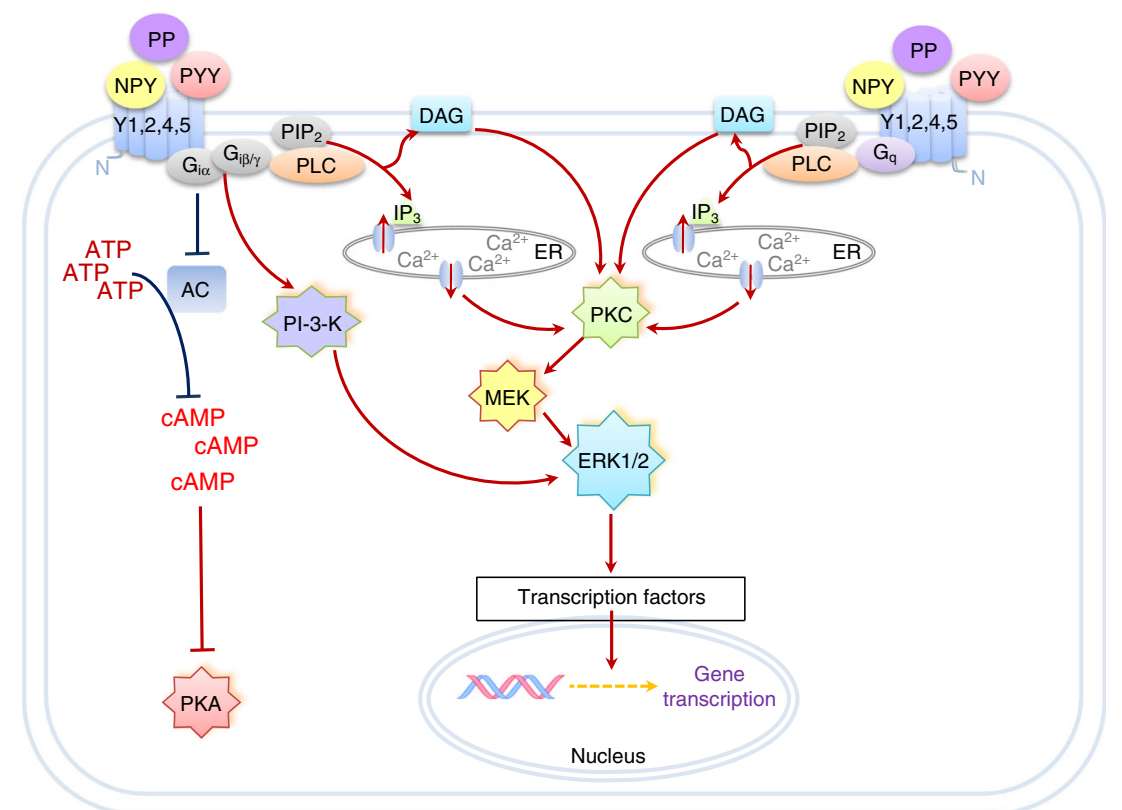

Fig. 1 Signalling pathways downstream of neuropeptide Y (NPY) receptor activation. The diagram shows the main pathways through which NPY receptor family members signal when activated by NPY, peptide YY (PYY) or pancreatic polypeptide (PP). All receptors couple via $\mathrm{G}_{\mathrm{i} \alpha}$ to inhibit adenylate cyclise (AC) and this represses signalling via the cAMP/protein kinase A (PKA) pathway. Activation of phospholipase $\mathrm{C}$ (PLC)-induced phosphatidylinositol bisphosphate $\left(\mathrm{PIP}_{2}\right)$ hydrolysis to diacylglycerol (DAG) and inositol 1,4,5-trisphosphate $\left(\mathrm{IP}_{3}\right)$ may occur via interaction with $\mathrm{G}_{\mathrm{q} \alpha}$ or $\mathrm{G}_{\mathrm{i} \beta / \gamma}$. DAG and $\mathrm{Ca}^{2+}$ mobilised following $\mathrm{IP}_{3}$ production activate protein kinase $\mathrm{C}$, which results in increased phosphorylation and activation of the mitogen-activated protein kinases (MAPKs) extracellular-regulated kinase (ERK)1 and ERK2, downstream of MAPK kinase (MEK). ERK1/2 may also be activated by signalling through the phosphatidylinositol-3-kinase (PI-3-K) cascade, and this modifies transcription of genes that can induce cell proliferation and/or decrease apoptosis. ER, endoplasmic reticulum 
consequent reduction in protein kinase (PKA) activity. In addition, in some cell types, $\mathrm{Y}$ class receptors can activate phospholipase $\mathrm{C}$ (PLC), either through coupling to $\mathrm{G}_{\mathrm{q}}$ or via the $\beta / \gamma$ subunits of $G_{i}$. Diacylglycerol, which is generated through PLC-mediated hydrolysis of phosphatidylinositol bisphosphate activates PKC, which stimulates phosphorylation of the mitogen-activated protein kinases (MAPKs) extracellular signal-regulated kinase 1/2 (ERK1/2) through activation of the upstream kinase known as MAPK kinase (MEK) (Fig. 1). A phosphatidylinositol-3-kinase (PI-3-K) pathway upstream of ERK1/2 activation has also been identified, which is thought to be activated via pertussis toxin-sensitive $G_{i}$ signalling [48]. Given the involvement of ERK1/2-mediated gene transcription, it is not surprising that activation of these receptors has been associated with driving proliferation in a number of tissues. A role for NPY receptors in neuroproliferation has been demonstrated by studies in which mice with a targeted deletion of NPY contain half as many dividing olfactory neuronal precursor cells as do wild-type mice, resulting in the development of significantly fewer olfactory neurons by adulthood [49]. In agreement with this, NPY has also been shown to cause proliferation of hippocampal neuroblasts and dentate gyrus cells [50,51]. The mitogenic action of NPY on neurons is thought to be dependent on PKC signalling and mediated by $\mathrm{Y} 1$, since a $\mathrm{Y} 1$, but not a $\mathrm{Y} 2$, receptor agonist enhanced proliferation and Y1 deletion abolished this effect [49]. In the periphery, NPY is mitogenic in a number of different tissues. It stimulates the proliferation of primary and clonal rat pre-adipocytes, and, similar to observation in neurons, these effects are mediated by Y1 receptors and involve the activation of ERK1/2 [34]. Furthermore, in vascular smooth muscle the mitogenic action of NPY is mediated by both $\mathrm{Y} 5$ and $\mathrm{Y} 1$ receptors [52] and, in cardiomyocytes, Y2 receptors are also associated with NPY stimulation of ERK1/2 [33]. Thus, there is strong evidence that $Y 1,2$ and 5 receptors can drive proliferation in a range of different cell types, raising the question as to whether these are common pathways that could be targeted to restore beta cell mass.

Interestingly, the most well characterised tissue in terms of the proliferative role of $\mathrm{Y} 1$ is the gut epithelium, where both PYY and NPY have been shown to stimulate colonic epithelial cell growth via PKC-dependent activation of ERK1/2 [53, 54]. This proliferative effect may also occur in human tissue, since human colon epithelium and the colonic adenocarcinoma cell line HT-29 express Y1 receptors [55], and when the human Y1 receptor is expressed in IEC-6 cells, a rat small intestine epithelial cell line, PYY treatment increases cell numbers [53]. Given the close relationship between the development of the gut and pancreas it is likely that these proliferative effects also occur in islet cells. Indeed, it has been demonstrated that Y1 receptor activation by NPY promotes bromodeoxyuridine (BrdU) incorporation into mouse islet beta cell DNA via ERK1/2 activation [56], consistent with a role for $\mathrm{Y} 1$ receptors in stimulating beta cell proliferation.

\section{Peptide YY, NPY receptors and apoptosis}

In addition to the reasonably well characterised proliferative effects of NPY receptors they may also play an important role in protecting cells from programmed cell death, with good evidence that activation of $\mathrm{Y} 1, \mathrm{Y} 2$ and $\mathrm{Y} 5$ receptors prevents apoptosis in neurons $[57,58]$. The mechanism of action has not been fully established, but in the case of $\mathrm{Y} 1$ receptors it has been demonstrated that receptor stimulation increases PKC epsilon activity [54], which couples via mitochondrial pathways to inhibit apoptosis [59]. PYY also exhibits antiinflammatory actions by inhibiting nuclear factor $\mathrm{KB}(\mathrm{NF}-\mathrm{kB})$ in pancreatic cells [60], a cascade that protects beta cells against cytokine-induced apoptosis [61]. Consistent with a beta cell-protective effect of PYY, we have recently demonstrated that ablation of PYY-expressing cells in the adult mouse causes a catastrophic disruption of islet architecture

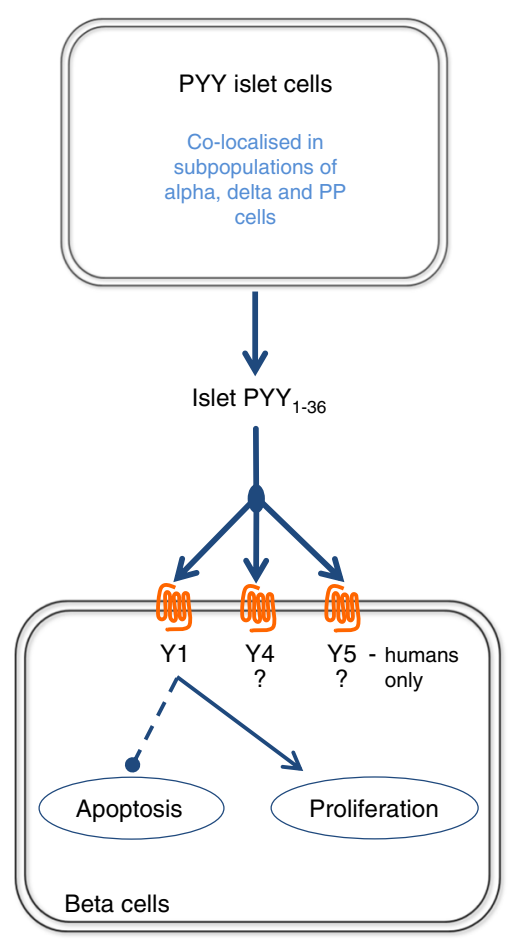

Fig. 2 Proposed role of islet PYY. Rodent islets express Y1 and Y4 receptors and human islets also express $\mathrm{Y} 5$ receptors. The $\mathrm{Y} 2$ receptor has not been identified in rodent or human islets, consistent with observations that $\mathrm{PYY}_{3-36}$, which is Y2-selective, does not alter insulin release or protect against toxic insults to beta cells. Since the major form of circulating PYY is $\mathrm{PYY}_{3-36}$, we propose that local release of $\mathrm{PYY}_{1-36}$ from subpopulations of alpha, delta and PP cells and the subsequent activation of Y1, Y4 and/or Y5 provides a mechanism by which PYY can increase beta cell proliferation and protect against beta cell apoptosis. Dotted line, inhibitory; solid line; stimulatory 
and beta cell destruction, with consequent development of insulin-dependent diabetes [40]. The possibility that PYY may provide trophic support to beta cells is supported by our demonstrations that beta cell loss following PYY cell ablation or streptozotocin (STZ)-induced diabetes is arrested by administration of a long-acting PYY analogue that has high affinity for $\mathrm{Y} 1$ and $\mathrm{Y} 2$ receptors [40]. Unsurprisingly, given that beta cells do not express the Y2 receptor subtype, beta cell loss was not rescued by the Y2-selective agonist $\mathrm{PYY}_{3-36}$. The preservation of beta cells by the PYY analogue was not associated with enhanced BrdU incorporation, suggesting that Y1 activation ameliorated insulin loss by protecting beta cells from an apoptotic signal triggered by the destruction of PYY-expressing cells rather than by increasing beta cell proliferation. In addition, we have observed direct anti-apoptotic effects of PYY analogues in vitro, where they protect MIN6 beta cells from cytokine-induced caspase 3/7 activation and from STZ- and $\mathrm{H}_{2} \mathrm{O}_{2}$-induced cell death (G. A. Bewick, S. Song and S. J. Persaud, unpublished results). Taken together, the currently available data provide compelling support for NPY receptor activation transducing a protective signal that can spare beta cells from apoptosis.

\section{Conclusion and future perspectives}

It is generally perceived that PYY contributes to the maintenance of fuel homeostasis through its central effects to reduce food intake. However, it is now becoming apparent that PYY and NPY receptors are potential targets for the preservation of beta cell mass. Identification of Y1 as the most abundant NPY receptor subtype in rodent and human islets, and the knowledge that this receptor promotes proliferation and protects against apoptosis in a range of other cell types, point to it being a prime candidate for further investigation (Fig. 2). However, there is a considerable amount of work to be done to define the physiological role of PYY in the control of beta cell mass. With regards to developing novel therapies for diabetes we will need to answer the following questions: Are Y1 receptors the most important for modulating beta cell mass or is there a role for $\mathrm{Y} 4$ receptors (or Y5 receptors in human islets)? Is the main mechanism of action through stimulation of beta cell proliferation or inhibition of apoptosis, or both? What are the intracellular mechanisms employed? Can the NPY receptor system be targeted to prevent the progression of type 1 diabetes? Additionally, we need to be mindful of the other roles of these receptors when considering them as targets for the treatment of diabetes. For example, targeting Y1 might have the unwanted side effect of increasing food intake, so if it is identified as the receptor on beta cells that mediates the beneficial effects of PYY, peripheral delivery of selective Y1 agonists may be required. This could be achieved by using pancreatic targeting systems that are currently under development [62], but it would complicate the drug design and increase development costs. Even though there remain hurdles to overcome, we anticipate that, by answering these questions, NPY receptors can become bona fide novel targets for the prevention and/or treatment of diabetes.

Funding Work in SJP's laboratory is funded by Diabetes UK, the Juvenile Diabetes Research Foundation (JDRF), the UK Medical Research Council and the European Foundation for the Study of Diabetes. Work in GAB's laboratory is funded by a JDRF project grant and by a National Institute for Health Research (NIHR) career development fellowship.

Duality of interest The authors declare that there is no duality of interest.

Contribution statement Both authors were responsible for the conception and design of the manuscript, contributed to drafting the article and revising it critically for important intellectual content and approved the version published.

\section{References}

1. Ryan EA, Paty BW, Senior PA et al (2005) Five-year follow-up after clinical islet transplantation. Diabetes 54:2060-2069

2. Tatemoto K, Mutt V (1980) Isolation of two novel candidate hormones using a chemical method for finding naturally occurring polypeptides. Nature 285:417-418

3. Adrian TE, Ferri GL, Bacarese-Hamilton AJ, Fuessl HS, Polak JM, Bloom SR (1985) Human distribution and release of a putative new gut hormone, peptide YY. Gastroenterology 89:1070-1077

4. Grandt D, Schimiczek M, Beglinger C et al (1994) Two molecular forms of peptide YY (PYY) are abundant in human blood: characterization of a radioimmunoassay recognizing PYY 1-36 and PYY 3-36. Regul Pept 51:151-159

5. Medeiros MD, Turner AJ (1994) Processing and metabolism of peptide-YY: pivotal roles of dipeptidylpeptidase-IV, aminopeptidase-P, and endopeptidase-24.11. Endocrinology 134: 2088-2094

6. Glavas MM, Grayson BE, Allen SE et al (2008) Characterization of brainstem peptide YY (PYY) neurons. J Comp Neurol 506:194-210

7. Gelegen C, Chandarana K, Choudhury AI et al (2012) Regulation of hindbrain Pyy expression by acute food deprivation, prolonged caloric restriction, and weight loss surgery in mice. Am J Physiol Endocrinol Metab 303:E659-E668

8. Upchurch BH, Fung BP, Rindi G, Ronco A, Leiter AB (1996) Peptide YY expression is an early event in colonic endocrine cell differentiation: evidence from normal and transgenic mice. Development 122:1157-1163

9. Roth KA, Kim S, Gordon JI (1992) Immunocytochemical studies suggest two pathways for enteroendocrine cell differentiation in the colon. Am J Physiol 263:G174-G180

10. Batterham RL, Bloom SR (2003) The gut hormone peptide YY regulates appetite. Ann NY Acad Sci 994:162-168

11. Batterham RL, Cowley MA, Small CJ et al (2002) Gut hormone PYY(3-36) physiologically inhibits food intake. Nature 418:650-654

12. Challis BG, Pinnock SB, Coll AP, Carter RN, Dickson SL, O'Rahilly S (2003) Acute effects of PYY3-36 on food intake and hypothalamic 
neuropeptide expression in the mouse. Biochem Biophys Res Commun 311:915-919

13. Chelikani PK, Haver AC, Reidelberger RD (2005) Intravenous infusion of peptide YY(3-36) potently inhibits food intake in rats. Endocrinology 146:879-888

14. Vrang N, Madsen AN, Tang-Christensen M, Hansen G, Larsen PJ (2006) PYY(3-36) reduces food intake and body weight and improves insulin sensitivity in rodent models of diet-induced obesity. Am J Physiol Regul Integr Comp Physiol 291:R367R375

15. Ghamari-Langroudi M, Colmers WF, Cone RD (2005) PYY3-36 inhibits the action potential firing activity of POMC neurons of arcuate nucleus through postsynaptic Y2 receptors. Cell Metab 2: 191-199

16. Baraboi ED, Michel C, Smith P, Thibaudeau K, Ferguson AV, Richard D (2010) Effects of albumin-conjugated PYY on food intake: the respective roles of the circumventricular organs and vagus nerve. Eur J Neurosci 32:826-839

17. Savage AP, Adrian TE, Carolan G, Chatterjee VK, Bloom SR (1987) Effects of peptide YY (PYY) on mouth to caecum intestinal transit time and on the rate of gastric emptying in healthy volunteers. Gut 28: $166-170$

18. Symersky T, Biemond I, Frolich M, Masclee AA (2005) Effect of peptide YY on pancreatico-biliary secretion in humans. Scand J Gastroenterol 40:944-949

19. La Sala MS, Hurtado MD, Brown AR et al (2013) Modulation of taste responsiveness by the satiation hormone peptide YY. FASEB J 27:5022-5033

20. Ali-Rachedi A, Varndell IM, Adrian TE et al (1984) Peptide YY (PYY) immunoreactivity is co-stored with glucagon-related immunoreactants in endocrine cells of the gut and pancreas. Histochemistry 80:487-491

21. Bottcher G, Ahren B, Lundquist I, Sundler F (1989) Peptide YY: intrapancreatic localization and effects on insulin and glucagon secretion in the mouse. Pancreas 4:282-288

22. Bottcher G, Sjoberg J, Ekman R, Hakanson R, Sundler F (1993) Peptide YY in the mammalian pancreas: immunocytochemical localization and immunochemical characterization. Regul Pept 43:115130

23. Suzuki A, Nakauchi H, Taniguchi H (2003) Glucagon-like peptide 1 (1-37) converts intestinal epithelial cells into insulin-producing cells. Proc Natl Acad Sci U S A 100:5034-5039

24. el-Salhy M, Grimelius L, Emson PC, Falkmer S (1987) Polypeptide YY- and neuropeptide Y-immunoreactive cells and nerves in the endocrine and exocrine pancreas of some vertebrates: an onto- and phylogenetic study. Histochem J 19:111-117

25. Jackerott M, Oster A, Larsson LI (1996) PYY in developing murine islet cells: comparisons to development of islet hormones, NPY, and BrdU incorporation. J Histochem Cytochem 44:809-817

26. Upchurch BH, Aponte GW, Leiter AB (1994) Expression of peptide $\mathrm{YY}$ in all four islet cell types in the developing mouse pancreas suggests a common peptide YY-producing progenitor. Development 120:245-252

27. Schonhoff S, Baggio L, Ratineau C et al (2005) Energy homeostasis and gastrointestinal endocrine differentiation do not require the anorectic hormone peptide YY. Mol Cell Biol 25:4189-4199

28. Larhammar D (1996) Structural diversity of receptors for neuropeptide Y, peptide YY and pancreatic polypeptide. Regul Pept 65:165174

29. Grandt D, Teyssen S, Schimiczek M et al (1992) Novel generation of hormone receptor specificity by amino terminal processing of peptide YY. Biochem Biophys Res Commun 186:1299-1306

30. Abbott CR, Small CJ, Kennedy AR et al (2005) Blockade of the neuropeptide Y Y2 receptor with the specific antagonist BIIE0246 attenuates the effect of endogenous and exogenous peptide YY(3-36) on food intake. Brain Res 1043:139-144
31. Koda S, Date Y, Murakami N et al (2005) The role of the vagal nerve in peripheral PYY3-36-induced feeding reduction in rats. Endocrinology 146:2369-2375

32. Abbott CR, Monteiro M, Small CJ et al (2005) The inhibitory effects of peripheral administration of peptide YY(3-36) and glucagon-like peptide-1 on food intake are attenuated by ablation of the vagalbrainstem-hypothalamic pathway. Brain Res 1044:127-131

33. Pellieux C, Sauthier T, Domenighetti A et al (2000) Neuropeptide Y (NPY) potentiates phenylephrine-induced mitogen-activated protein kinase activation in primary cardiomyocytes via NPY Y5 receptors. Proc Natl Acad Sci U S A 97:1595-1600

34. Yang K, Guan H, Arany E, Hill DJ, Cao X (2008) Neuropeptide Y is produced in visceral adipose tissue and promotes proliferation of adipocyte precursor cells via the Y1 receptor. FASEB J 22:24522464

35. Mannon PJ, Kanungo A, Mannon RB, Ludwig KA (1999) Peptide YY/neuropeptide Y Y1 receptor expression in the epithelium and mucosal nerves of the human colon. Regul Pept 83:11-19

36. Amisten S, Salehi A, Rorsman P, Jones PM, Persaud SJ (2013) An atlas and functional analysis of G-protein coupled receptors in human islets of Langerhans. Pharmacol Ther 139:359-391

37. Burcelin R, Brunner H, Seydoux J, Thorensa B, Pedrazzini T (2001) Increased insulin concentrations and glucose storage in neuropeptide Y Y1 receptor-deficient mice. Peptides 22:421-427

38. Morgan DG, Kulkarni RN, Hurley JD et al (1998) Inhibition of glucose stimulated insulin secretion by neuropeptide $\mathrm{Y}$ is mediated via the $\mathrm{Y} 1$ receptor and inhibition of adenylyl cyclase in RIN 5AH rat insulinoma cells. Diabetologia 41:1482-1491

39. Chandarana K, Gelegen C, Irvine EE et al (2013) Peripheral activation of the Y2-receptor promotes secretion of GLP-1 and improves glucose tolerance. Mol Metab 2:142-152

40. Sam AH, Gunner DJ, King A et al (2012) Selective ablation of peptide YY cells in adult mice reveals their role in beta cell survival. Gastroenterology 143:459-468

41. Boey D, Lin S, Karl T et al (2006) Peptide YY ablation in mice leads to the development of hyperinsulinaemia and obesity. Diabetologia 49:1360-1370

42. Lundquist I, Sundler F, Ahren B, Alumets J, Hakanson R (1979) Somatostatin, pancreatic polypeptide, substance $\mathrm{P}$, and neurotensin: cellular distribution and effects on stimulated insulin secretion in the mouse. Endocrinology 104:832-838

43. Nieuwenhuizen AG, Karlsson S, Fridolf T, Ahren B (1994) Mechanisms underlying the insulinostatic effect of peptide YY in mouse pancreatic islets. Diabetologia 37:871-878

44. Ahren B, Larsson H (1996) Peptide YY does not inhibit glucosestimulated insulin secretion in humans. Eur J Endocrinol 134:362-365

45. van den Hoek AM, Heijboer AC, Corssmit EP et al (2004) PYY3-36 reinforces insulin action on glucose disposal in mice fed a high-fat diet. Diabetes 53:1949-1952

46. Liu G, Arnaud-Dabernat S, Kritzik MR, Kayali AG, Zhang YQ, Sarvetnick N (2006) PYY in the expanding pancreatic epithelium. Endocrine 30:103-112

47. Kahan BW, Jacobson LM, Hullett DA et al (2003) Pancreatic precursors and differentiated islet cell types from murine embryonic stem cells: an in vitro model to study islet differentiation. Diabetes 52:2016-2024

48. Goldberg Y, Taimor G, Piper HM, Schluter KD (1998) Intracellular signaling leads to the hypertrophic effect of neuropeptide $\mathrm{Y}$. Am J Physiol 275:C1207-C1215

49. Decressac M, Wright B, David B et al (2011) Exogenous neuropeptide Y promotes in vivo hippocampal neurogenesis. Hippocampus 21: $233-238$

50. Hansel DE, Eipper BA, Ronnett GV (2001) Neuropeptide Y functions as a neuroproliferative factor. Nature 410:940-944

51. Howell OW, Scharfman HE, Herzog H, Sundstrom LE, Beck-Sickinger A, Gray WP (2003) Neuropeptide Y is 
neuroproliferative for post-natal hippocampal precursor cells. J Neurochem 86:646-659

52. Nie M, Selbie LA (1998) Neuropeptide Y Y-1 and Y-2 receptormediated stimulation of mitogen-activated protein kinase activity. Regul Pept 75-6:207-213

53. Mannon PJ, Mele JM (2000) Peptide YY Y1 receptor activates mitogen-activated protein kinase and proliferation in gut epithelial cells via the epidermal growth factor receptor. Biochem J 350:655661

54. Mannon PJ (2002) Peptide YY as a growth factor for intestinal epithelium. Peptides 23:383-388

55. Mannon PJ, Mervin SJ, Sheriff-Carter KD (1994) Characterization of a Y1-preferring NPY/PYY receptor in HT-29 cells. Am J Physiol 267:G901-G907

56. Cho YR, Kim CW (2004) Neuropeptide Y promotes beta-cell replication via extracellular signal-regulated kinase activation. Biochem Biophys Res Commun 314:773-780
57. Thiriet N, Deng X, Solinas M et al (2005) Neuropeptide Y protects against methamphetamine-induced neuronal apoptosis in the mouse striatum. J Neurosci 25:5273-5279

58. Wu YF, Li SB (2005) Neuropeptide Y expression in mouse hippocampus and its role in neuronal excitotoxicity. Acta Pharmacol Sin 26:63-68

59. Basu A, Sivaprasad U (2007) Protein kinase C $\varepsilon$ makes the life and death decision. Cell Signal 19:1633-1642

60. Vona-Davis L, McFadden DW (2007) PYY and the pancreas: inhibition of tumor growth and inflammation. Peptides 28:334-338

61. Eizirik DL, Mandrup-Poulsen T (2001) A choice of death - the signal-transduction of immune-mediated beta-cell apoptosis. Diabetologia 44:2115-2133

62. Ueberberg S, Ziegler D, Schechinger W et al (2010) In vitro phage display in a rat beta cell line: a simple approach for the generation of a single-chain antibody targeting a novel beta cell-specific epitope. Diabetologia 53:1384-1394 